\title{
CCA leachability of slow dried three major bamboo species of Bangladesh
}

\author{
A K LAHIRY \\ Office of the Timber Products Specialist, Wood Tesling and Research Laboratory, Rural Electrification Board \\ (REB), REB HQ Building, Joarsahara, Khilkhet, Dhaka 1229, Bangladesh
}

MS received 23 May 1997 ; revised 23 December 1997

\begin{abstract}
Chronjated copper arenate (CCA) leachability tests on full cell pressure imprignated (vith 2-3\% CCA solution) and slow dried (six months air-drying under cover) bamboo hlock of three niajor banboo species of Bangladesh revealed initial insigaificant leaching of $\mathrm{CCA}$ within first weok and no leaching in mext weck. Use of low concentration of CCA, release of particle form of $\mathrm{CCA}$ due to exposure of bambon blocks by cutting and presence of water soluble extractives in bamboo might be the canses for initial leaching of $\mathrm{CCA}$.
\end{abstract}

Keywords. CCA leachability; slow dried bamboo; fixation,

\section{Introduction}

The bamboo is distributed world wide, especially in tropical areas. It is socioeconomically and environmentally important village and forest crop of Bangladesh (Lahiry 1995a). Besides ecological inportance, bamboo is the main raw material for rural housing and also the principal source of withes for making basketry and matting (Banik 1998). From the environmental and economical point of views, the service life of bamboo and bamboo products have to be increised to control the present reserve. The untreated bamboo is perishable. The bamboo reserves can be increased two times (e.g. from 2-3 years to 5-6 years in ground contact) by any means (Lahiry 1995a). The CCA sill treated bamboo has been used in India as exterior claddings and as rooting support for over 33 years (Kumar and Dobriyal 1988). Such long service life has not been repinted when used in ground and water (Lahiry 1995a). Effective CCA treatment of bamboo depends on penetratabilicy, retainability, :nd leachability of CCA. Most of the research studies on preservation of bamboos have been condicted, in India by Purashothati (1963), Singh (1976). Singh and Tewari (1979, [981), Liese (1980), Tewali (1981), Kumar and Dobriyal (1988), Choudhury (1993), and in Indonesia by Sultoni (1985, 1988). In Bangladesh the researches an preservative treatment of bamboos have been carried out by Salehuddin (1985), Latif et ol (1987). Jathiry (1994, 1995a, b, c. $1996,1997)$ and Lahiry et al (1996). The CCA treatability and grades of treatment by full cell pressure method at green, dry and round conditions of major bamboo species (Bambusa balcooa, B. vulgaris, B. Ulda and Melocama baccifera) of Banglatesh and their nonsplitting technique during pressure treatment have been l'eported (Lahiry 1994, 1995a, b, 1996, 1997; Lahiry et al 1996). The CCA leachability of these bamboo species and others has not been reported earlier. The leachability of CCA treated green African mountain bamboo (Arundinaria alpina) have been reported (Slob ot al 1989). The leaching tests carried out by them on CCA impregnated bamboo by Boucherie method, revealed that an average of $15 \%$ $\mathrm{Cu}, 17 \% \mathrm{Cr}$ and $34 \%$ As could be removed by submerging $2 \mathrm{~cm}$ bamboo rings in water. A good fixalion is possible when sufficiently high $(5-10 \%)$ concentrations of CCA are used, fixation is mainly the result of formation of $\mathrm{Cu}-\mathrm{Cr}-\mathrm{As}$ complexes in the vascular bundles, in sawdust of bamboo the fixation takes place through the formation of CCA complexes with the bamboo constituentscellulose and lignin, in this process, fixation of chromium onto cellulose and lignin is the key step (Slob et al 1989).

It is an attempt to study the leachability of CCA-C treated three major bamboo species of Bangladesh after slow air-diying the CCA-C treated bamboo for six months under cover for the environmental safety and effectiveness of CCA treated batnboo in ground and water coniacl use.

\section{Materials and methods}

The dry borak bamboo (Bambusa balcooa Roxb.), bajja bamboc ( $B$. vilgaris Schtad. ex Wendle) and muli bamboo (Melocanta baccifera (Roxb.) Kurz.), full cell pressure treated with CCA-C (with $2-3 \%$ CCA-C solution) and air-dried in room temperature for six months were the matertals for leachability test. Due to limited 
facilities, the leachability test was carried out by the method developed by the author with partial modification of AWPA Standard (AWPA Standard Ell 1987). About equal weight of treated bamboo blocks $(10 \mathrm{~g} \pm 0.75$ at 14-15\% MC, table 1) from internode was taken and dipped in $100 \mathrm{ml}$ of ordinary tap water for leaching of CCA-C. The leachate was analyzed each after $24 \mathrm{~h}$, continuously for 7 days, and at the end of 15 th day (table 1). Before each analysis, the block of bamboo was agitated in water for $15 \mathrm{~min}$ with the help of magnetic stirrer. Every assay/analysis of leachate was compared with control blank water to find out the actual leaching in same continuols $100 \mathrm{ml}$ of water used from the beginning to cnd of all tests. Before and after leaching, the level of internodal retcntion ( $w / w \%=w t$. to wt.\% and $w / v$ ) of bamboo was found out by analysis (table 1). The preleaching retention was determined from different bamboo blocks of original bamboo.

For weight mensurement, an analytical optical balance (Metler H35AR) was used. Moisture content (MC) of bamboos was measured with a calibrated resistance type digital motsture meter (Delmhorst). All the analyses (retention and concentration of leachate) were carried out spectroscopically with an X-ray ASOMA analyzer (model 8620) following standard method (AWPA Standard A9 1990). The chemical balance of individual component of $\mathrm{CCA}-\mathrm{C}$ was determined from a]l analyses.

\section{Results and discussion}

The results of lenching of CCA-C from three bamboo species have been presented in table ] and discussed as follows.

\subsection{Leaching rine and causes}

The present method of leachabijity lests reveals that leaching of $\mathrm{CCA}-\mathrm{C}$ only occurs in first week in all three bamboo species and shows no leaching in next week. It was observed that after completion of initial leaching of CCA-C from all types of bamboos, leachates ( $00 \mathrm{ml}$ tap water wilh bamboo block) were straw in colour and gelatinous in nature. The same gelatinous nature was also observed in water dipped with untreated bamboo blocks which indicates that the initial leaching only occurs due to presence of nonfixative type of substances e.g. water soluble starches, extraclives etc in bamboo, as reported possible in timber by pizzi et al (1986). Use of low concentration of CCA-C and release of particle form of CCA.C due to exposure of bamboo blocks by cuting might be the secondary causes of leaching. Due to slow drying of full cell pressure treated bamboo, the components of CCA-C fixes with the celluIose and lignin of banboo. This initial leaching would not be siguificant if CCA-C treated intact bamboo is used in ground or water, because in such conditions the most leaching areas of bamboo piece will not be exposed compared to the test sample. Several years will be required for the completion of initial leaching-

\subsection{Leaching amount and characteristics}

The leachability test from bamboo block permits leaching of $\mathrm{CCA}-\mathrm{C}$ components preferably from surfaces rather than inner most or central portion where leaching may not occur at all. Moreover different anatomical structure of different bamboo species responsible to release differential amount of CCA-C e.g. the texture of $M$. baccifera is rather fine. Due to these phenomena of leaching, the different results reflected in leachate and post leaching retention. As such the leaching characteristics of individual component of CCA-C have been analyzed (discussed) separately as follows.

3.2a From retention: The chemical balances of $\mathrm{CCA}$. before and after leaching wes found within the limit of CCA type (AWPA Standard P5 1991) in all bamboo species with the marginal insignificant exception in $\mathrm{As}_{2} \mathrm{O}_{5}$ in $B$. balcooa and $M$. baccifera, where the corresponting balances wete found as $27.91 \%$ and $29.66 \%$ after leaching ( $30 \%$ is minimum normal). But the leachnte showed different. results.

$3.2 \mathrm{~b}$ From learhate: The obtained average chemical balance of leachate in three bamboo species were $64.95 \%$ $\mathrm{CrO}_{3}, 1673 \%$ CuO and $1832 \% \mathrm{As}_{2} \mathrm{O}_{5}$ (equivalent to CCA type $A$ ) against expected nomal CCA-C type of $44.5-50.5 \% \quad \mathrm{CrO}_{3}, \quad 17-21 \%$ CuO and $30-38 \% \quad \mathrm{As}_{2} \mathrm{O}_{5}$ (AWPA Standard P5 1991). This imbalance in leachate is the indication of higher initial leaching of $\mathrm{CrO}_{3}$ rather than $\mathrm{CuO}$ and $\mathrm{A}_{3} \mathrm{O}_{5}$. Since the leaching of $\mathrm{CCA}-\mathrm{C}$ was stopped in second week, the necessary key step for fixation of chromitum onto cellulose and lignifi is not significant here as reported earlier in $A$. alpina by Slob et al (1989). Slob et al (1989) repotted that good fixation is possible when sufficiently high (5-10\%) concentration of CCA are used. In the present study, good fixation was obcained with low (2-3\%) concentration of $\mathrm{CCA}$, because the treated bamboo was dried slowiy for six months.

\subsection{Fuation tine}

Slow fixation of CCA treated bamboo was found effective but too long to follow. Accelerated fixation process of CCA treated bamboo by higher temperature, as repolted for timbers (Cooper and Ung 1992; Artymko and Cooper 1994; Boone et al 1994), would be developed if time is a factor for inlplementation. 
CCA leachability of major bamboo species of Bangladesh

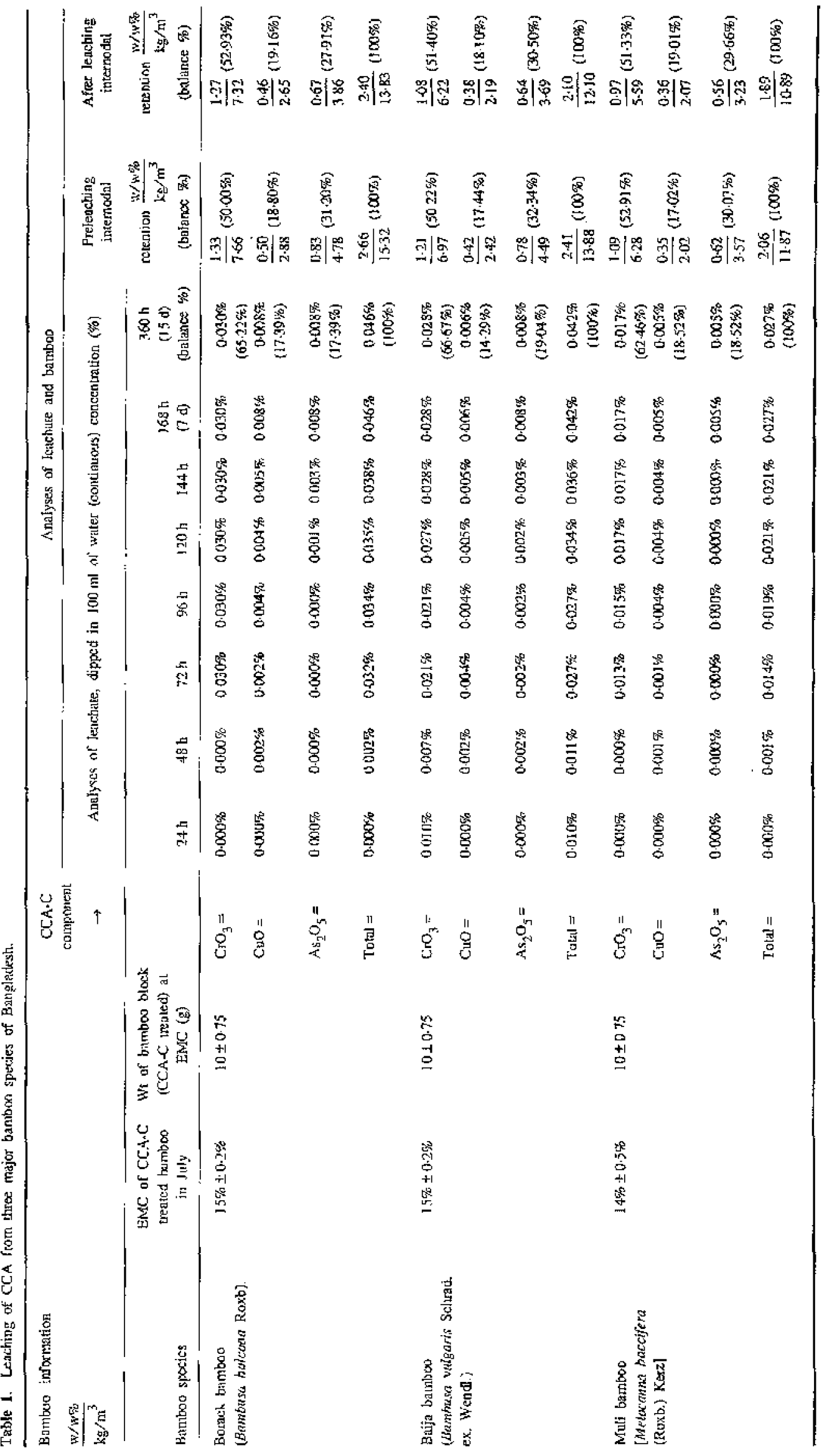




\subsection{Removal of extractives}

During post treatment weathering or inmersion in water, the extractives may be removed enough as teported possible in sundri wood (Heritierca fontes) by Lahiry (1994). Leachability of CCA treated bamboo-treated at green vs at kiln-dried vs at weathered and air-dried conditions require to be found out, because presence of water soluble extractives in timber may enhance leaching as reported by Pizzi et al (1986).

\section{Conclusion}

The slow fixation of CCA-C treated three major bamboo species of Bangladesh at low concentration was found significantly effective for ground and water contact use compared to higher concentrations reported earlier for other species. CCA treated bamboo shall have to be dried slowly for proper fixation before outdoor use.

\section{Acknowledgement}

I thank two of nny Laboratory Technicians, Farid Uddin Ahmed and Md. Khorshed Alam for their help during tests.

\section{References}

Artymko J and Cooper P A 1994 Effects of fuxation temperature and humidity on CCA leaching and effectiveness against brown rot fungi and eastern subteranean termites, $\mathrm{M} \mathrm{Sc}$ theșiș, Toronto Universily, Toronto

AWPA Standard A9 1990 Statdard mothod for analysis of treated wood and treating solutions by $X$-rity spectroscopy (Book of Standards Amer. Wood Prescryer's Association) p. 4

AWPA Standand PS 1991 Standards for waterborne preserkatives (Book of Stundards Amer. Wood Proserver's Association) p. 4

AWPA Standard E11 1987 Standard merhod for determining the leachability of wood preservarives (Book of Standards Amer. Wood Preserver's Association) p. 2

Banik R L 1998 Bone Biggyan Patrica 1865

Bootle R S, Winandy J E and Fuller J J 1994 Enhanced preservative fixation by redrying CCA treated lumber (USA: USDA For Ser. For Prod Lab)

Choudhury M Y 1993 Plysical and chemical treatments of bomboo for strength and durability, Chinese Acad. Forestry Int Trop. Tinh. Organiz, Yolohami, Japan, in Bamboo and its use, Int. symp on indistrial ase of Bamboo, Bejing. China, pp 155-157

Cooper $\mathrm{P} A$ and Ling $\mathrm{Y} \mathrm{T} 1992$ Accelerated fixalion of $\mathrm{CCA}$ treated poles (Cannda: Toronto University)

Kumar $S$ and Dotriyal P B 1,988 preservalive traatment of bamboo for structural uses, in Bamboo Current Research, Proc. Int. Bamboo Workshop, Cochin, India (KFRI, India) and (IDRC, Catrada) pp 199-206

Labiry A K $1994 J$. Thinh. Dev. Assoc. (India) 4020

Lahiry A K 1995a J. Timb. Dev. Assoc. (India) 4110

Latiry A K $1995 b$ Wood preservation science (Bangali) (Dhaka: Bangla Academy) 1 ed. vol. 1, p. 184

Lahiry A K 1995c Wood preservation science (Bangali) (Dhaka: Bangla Academy) 1 ed. vol. 2, p. 211

Lahiry A K 1996 CCA treatability of 100 timbers of Bangladesh; Intemat Res. Group on Wood Prcsery. Documenl No. [RG/WP/40069, p. ]7

Lahity A K 1997 J. Sci. \& Ind. Res. (India) 5639

Lahity A. K, Begurn S, Ilias G N M, Malin Sheikh M A. Fakir M A B and Hossain M I 1996 An effective preservative treatmen of borak bamboo (Bambusa balcooa Roxb.) Internat. Res. Group on Wood Preserv. Document No. IRG/WP/40070 p. 17

Latif $M$ A. Dasgupta $S$ R, De B C and Zaman $Y$ L 1987 Presenative treathent of bamboo and low cost housing. Bulletin 3 Wood Preservation Series (Bangladesh: BFRT) p. 5

Liese W 1980 Presenvation bamboos, it Bamboo Research in A sia (Canada: IDRC) pp. 165-172.

Purshotham A 1963 Timber Dryen' Preser. Assor. (India) 9 pp, $1-2$

Pizzi A, Contradie W E and Bariska M 1986 Polyfaronoid tamins ,rom a catse of soft rot fallure to the 'missing link' between lignin and nicro-distibution heories; Int. Res. Group on Wood Preserv. Document No. IRG Doc. No. IRG/WP/3359

Singh B 1976 Studies on the dlffusion of water soluble wood preserving chemicals in bamboo, $\mathrm{Ph}$ D Thesis, Punjabi University, Patiala, India

Singh B and Tewati M C 1979 J. Indlan Acal. Wood Sci. 10 68

Singh B and Tewari M C $1981 \mathrm{~J}$. Timb. Dev. Assoc. (India) 2768

Sultoni Achmad 1985 Tradifional preservation of banboo in Java, in Recent Research on Bamboos (Canada: IDRC) pp. $349-357$

Sultoni Achmad 1988 A simple and cheap method of bamboo preservation, in Bamboos Curren Research. Proc. Int Bamboo Workshon, Coctin (India) (India: KFRD) and (Canadn: IDRC) pp. $209-2$ ! $\mathrm{i}$

Salehuddin A В M 1985 REB mantal for preservative treatment of banhoo culns-improved setp displacenent method oblaka: REB) p. 4

Slob J W, Nargawe $P F$, de Leer E and Donker J 1989 CCA inpregnation of bambooleaching and fixation characteristics (Netherlands: Delft University of Tectmology, Water Chemistry Group) pp. 321-335

Tewari MC 1981 Recent sudies on the protection of bamboo against deterioration, in Proc. Group 503 XUI TUFRO World Cong. Japen 